\title{
Gambaran kapasitas fisik atlet Papua: Kajian menuju PON XX Papua
}

\author{
Miftah Fariz Prima Putra*, Saharuddin Ita \\ Program Studi Ilmu Keolahragaan, Fakultas Ilmu Keolahragaan, Universitas Cenderawasih \\ Kampus Uncen Abepura, Jalan Pendidikan No. 1, Abepura, Jayapura 99351, Indonesia. \\ * Corresponding Author. Email: mifpputra@gmail.com
}

Received: 10 November 2019; Revised: 9 December 2019; Accepted: 12 December 2019

\begin{abstract}
Abstrak
Tujuan penelitian ini adalah untuk (1) mengungkap kondisi fisik atlet Papua, (2) menghubungkan antara variabel IMT, kecepatan, dan kekuatan dengan VO2max, (3) membandingkan kemampuan fisik atlet Papua antara cabor atletik, bola voli dan tarung derajat. Metode deskriptif dengan desain ex post facto akan digunakan dalam studi tersebut. Sebanyak 132 atlet Papua (92 laki-laki dan 40 perempuan) cabor atletik, bola voli dan tarung derajat akan dijadikan sampel penelitian. Hasil penelitian menemukan bahwa (1) kondisi IMT atlet Papua rata-rata berkriteria normal, pada aspek kekuatan rata-rata berkriteria sangat kurang untuk atlet laki-laki dan kurang untuk perempuan, pada aspek kecepatan dan VO2max rata-rata dalam kondisi sangat kurang, (2) terdapat hubungan antara IMT dan kekuatan dengan VO2max, sedangkan dengan kecepatan tidak ada hubungan yang signifikan, (3) terdapat perbedaan yang signifikan pada IMT, kecepatan dan VO2max atlet antara cabor atletik, bola voli dan tarung derajat. Untuk kondisi fisik kekuatan tidak ditemukan perbedaan yang signifikan.
\end{abstract}

Kata Kunci: IMT; kecepatan; kekuatan; VO2max; Papua

\section{Profile of Papua athlete physical capability: Study towards Papua PON XX}

\begin{abstract}
The purpose of this study was to reveal (1) how the physical condition of Papuan athletes, (2) is there a relationship between BMI, speed, and strength with VO2max, (3) whether there are differences in physical abilities of Papuan athletes between athletic sports, volleyball and fighting degrees. Descriptive method with ex post facto design will be used in the study. As many as 132 Papuan athletes (92 male and 40 female) athletic sports, volleyball and fighting will be used as research samples. The results of the study found that (1) the BMI conditions of the average Papuan athlete had normal criteria, in the aspect of the average strength the criteria were very less for male athletes and less for women, in the aspect of speed and VO2max in the average conditions were very less, (2) there is a relationship between BMI and strength with VO2max, whereas for speed there is no significant relationship, (3) there is a significant difference in BMI, speed and VO2max athletes between athletic sports, volleyball and fighting degrees. For the physical condition of strength, no significant difference was found.
\end{abstract}

Keywords: BMI; speed; power; VO2max; Papua

How to Cite: Putra, M., \& Ita, S. (2019). Gambaran kapasitas fisik atlet Papua: Kajian menuju PON XX Papua. Jurnal Keolahragaan, 7(2), 135-145. doi:https://doi.org/10.21831/jk.v7i2.26967

doi

https://doi.org/10.21831/jk.v7i2.26967

\section{PENDAHULUAN}

Terbitnya Surat keputusan Menteri Pemuda dan Olahraga Nomor 0110 tahun 2014 tanggal 2 April 2014 yang menetapkan Provinsi Papua sebagai tuan rumah penyelengaraan Pekan Olahraga Nasional (PON) ke-XX tahun 2020 merupakan tonggak sejarah dalam olahraga Papua. Pasalnya, hal ini merupakan untuk pertama kalinya Provinsi Papua terpilih sebagai tuan rumah dalam even olahraga terbesar Indonesia.
Meskipun berlabel olahraga terakbar nasional, namun malangnya kajian tentang atlet PON juga belum banyak ditemukan. Hasil pencarian di Garba Rujukan Digital (Garuda) yang beralamat di www.garuda.ristekdikti.go.id dengan kata kunci "kondisi fisik atlet PON" menemukan 3 artikel yang relevan. Dari artikel tersebut, terdapat dua artikel yang mengkaji kondisi fisik atlet dalam PON 2008 dan 2012. Namun, kajian tersebut terbatas pada atlet bola voli indor putri saja. Dua artikel lainnya juga 
terbatas pada satu cabang olahraga (cabor), yaitu karate (Purba, 2016) dan tarung derajat (Hambali et al., 2016). Pencarian dilakukan lagi di garuda dengan kata kunci yang lebih luas, yaitu "atlet PON" dan hasilnya didapat 22 artikel. Dari hasil tersebut, tema artikel sangat beragam. Misalnya, tentang analisis kebijakan training center atlet PON (Rahmat, 2017), pengaruh doping (Sujatno, 2001), latihan fisik (Razak, 2011), kontribusi IQ dan EQ (Aggraeni, 2013), manajemen atlet (Septian, 2013), cidera olahraga (Junaidi, 2013), dan kepercayaan diri (Dimyati, 2004). Studi yang secara khusus diarahkan untuk mengungkap kondisi fisik seperti IMT, kecepatan, kekuatan, fleksibilitas, keseimbangan, dan VO2max yang dimiliki atlet PON pada beragam cabor belum ditemukan di lapangan.

Padahal, data tentang kondisi fisik atlet sangat penting untuk menyusun periodisasi latihan. Informasi tentang kondisi atau kemampuan fisik yang dimiliki atlet menjadi sangat urgen ketika akan dilakukan pembinaan dan pengembangan kondisi fisik atlet secara keseluruhan. Coba bayangkan bagaimana jadinya ketika seorang pelatih memberikan program latihan fisik, namun Ia tidak mengetahui kondisi atau kemampuan awal atletnya. Program yang diberikan tersebut sangat mungkin tidak tepat sasaran karena tidak sesuai dengan kondisi dan kebutuhan atlet.

Tengok apa yang dilakukan oleh Tim Jawa Timur! Untuk menghadapi PON XX Papua, mereka mengambil konsultan dari Australia, Dr. Greg Wilson, yang difokuskan untuk memberikan masukan bertalian dengan pembentukan kondisi fisik atlet Jawa Timur. Pengurus cabor Jawa Timur percaya bahwa tanpa kondisi fisik yang prima maka sukar untuk dapat berprestasi optimal dalam PON, dimana pesertanya adalah atletatlet level nasional dari seluruh Provinsi. Oleh karena itu, menggenjot kamampuan fisik atlet diyakini menjadi determinan utama mengapai prestasi dalam PON.

Pengetahuan tentang bagaimana kondisi atlet menjadi salah satu faktor utama yang harus dipertimbangkan dalam proses latihan guna mencapai prestasi yang tinggi. Tujuan utamanya adalah untuk meningkatkan potensi fungsional atlet dan mengembangkan kemampuan biomotor ke derajat yang paling tinggi (Bompa \& Haff, 2009). Biomotor yang dimaksud oleh Bompa di atas antara lain kekuatan (strenght), kecepatan (speed), daya tahan (VO2max), kelentukan (flexibility) dan koordinasi.
Dewasa ini, dalam olahraga kompetitif, komponen fisik seperi IMT, kekuatan, kecepatan dan VO2max sangat penting diketahui bagaimana kondisinya. IMT dipercayai dapat menjadi indikator atau menggambarkan kadar adipositas dalam tubuh seseorang. Apabila atlet bermasalah dengan status gizinya maka sukar rasanya atlet tersebut akan dapat berprestasi. Variabel kekuatan juga menjadi penting karena olahraga kompetitif kerap mengedepankan aspek kekuatan, baik kekuatan otot lengan, perut maupun kaki. Variabel VO2max merupakan faktor yang sangat penting dalam olahraga. Hal ini disebabakan karena kompetisi atau pertandingan olahraga acapkali dilakukan dalam kurun waktu yang tidak singkat dan membutuhkan daya tahan (endurance) yang baik. Variabel lain yang tidak kalah penting adalah kecepatan. Sebagai contoh, dengan kecepatan seorang pegulat dapat melakukan reversal dengan cepat, seorang petinju dapat melakukan job secepat kilat, seorang Taekwondoin dapat melakukan tendangan dengan cepat, dan seorang pelari dapat berlari sangat kencang. Itu artinya, dalam olahraga prestasi, kecepatan mengambil posisi yang sangat penting dan menentukan.

Pertanyaannya kemudian, bagaimana dengan kondisi fisik atlet PON Papua? Data empirik bertalian dengan kemampuan fisik atlet, seperti kecepatan, kekuatan, fleksibilitas, keseimbangan dan VO2max atlet belum ada. Atas dasar uraian tersebut maka tujuan utama penelitian tersebut adalah untuk (1) mengungkap kondisi fisik atlet Papua yang diproyeksikan memperkuat tim Papua dalam PON XX tahun 2020, (2) mengetahui hubungan antara variabel IMT, kecepatan, kekuatan, dengan VO2max, (3) membandingkan kemampuan fisik atlet Papua antara cabor atletik, bola voli dan tarung derajat.

\section{METODE}

Untuk mencapai tujuan penelitian, metode deskriptif dengan desain ex post facto digunakan. Menurut Ary et al. (2010) descriptive research is not generally directed toward hypotesis testing. The aim to describe "what exists" with respect to variables or conditions in situation". Melalui desain penelitian tersebut diungkap bagaimana kemampuan fisik atlet Papua, hubungan antar variabel serta perbedaan kondisi fisik atlet antar cabor.

Subjek penelitian ini terdiri dari dua jenis, yaitu cabor dan atlet. Subjek cabor menyesuaikan dengan cabor yang diperlombakan dalam PON XX Papua sebanyak 37 Cabor. Meski terdapat 37 
cabor yang diperlombakan, dalam studi ini hanya diambil 3 cabor secara purposive-random sampling yang mewakili karakteristik cabor beladiri, permainan dan terukur. Setelah menentukan subjek cabor, langkah berikutnya adalah menentukan subjek atlet. Untuk atlet tidak dilakukan pengambilan sampel, namun melibatkan seluruh atlet yang ada di masing-masing cabor. Berikut adalah gambaran subjek penelitiannya (Tabel 1).

Table 1. Deskripsi Sampel Penelitian

\begin{tabular}{lccc}
\hline \multirow{2}{*}{ Cabang Olahraga } & \multicolumn{2}{c}{ Jumlah } & \multirow{2}{*}{ Total } \\
\cline { 2 - 3 } & L & P & \\
\hline Atletik & 53 & 19 & 72 \\
Bola voli & 21 & 9 & 30 \\
Tarung derajat & 18 & 12 & 30 \\
\hline Total & 92 & 40 & 132 \\
\hline
\end{tabular}

Dari Tabel 1 tampak bahwa sampel cabor terdiri dari cabor atletik dengan jumlah subjek penelitian sebanyak 72 atlet (53 laki-laki dan 19 perempuan) dengan rata-rata usia 20 tahun, bola voli sebanyak 30 atlet (21 laki-laki dan 9 perempuan) dengan rata-rata usia 21 tahun, tarung derajat sebanyak 30 atlet (18 laki-laki dan 12 perempuan) dengan rata-rata usia 22 tahun. Total atlet yang dijadikan subjek penelitian adalah 132 atlet (92 laki-laki dan 40 perempuan).

Dalam penelitian ini terdapat 4 variabel yang diukur dengan instrumen yang sudah terstandar. Pengambilan data penelitian dibantu oleh 12 mahasiswa tingkat akhir yang ditempatkan di setiap pos pengambilan data. Untuk menjaga kualitas data yang diambil maka mahasiswa diberikan pembekalan bertalian dengan prosedur atau protap pengambilan data yang dilakukan. Tabel 2 adalah gambaran instrumen dan jumlah petugas pengambil data.

Tabel 2. Instrumen penelitian

\begin{tabular}{clll}
\hline No. & Variabel & Instrumen & Petugas \\
\hline 1. & IMT & $\begin{array}{l}\text { Timbangan BB } \\
\text { dan Meteran }\end{array}$ & 2 Mahasiswa \\
2. & Kecepatan & Lari 30 meter & 2 Mahasiswa \\
3. & Kekuatan & Push-up & 2 Mahasiswa \\
4. & VO2max & Multi-Fitness & 6 Mahasiswa \\
& & Test (MFT) & \\
\hline
\end{tabular}

Jadwal pengambilan data dilakukan dengan cara berkoordinasi dengan KONI Provinsi Papua yang selanjutnya KONI akan berkoordinasi dengan pengprov cabor untuk menentukan kapan dan cabor apa yang terlebih dahulu dilakukan pengambilan datanya. Tim peneliti akan menyiapkan hal-hal secara teknis berkaitan dengan pengambilan data di GOR FIK UNCEN. Data yang terkumpul dianalisis secara deskriptif, yaitu menggunakan mean, standar deviasi, serta persentase. Teknik analisis yang berikutnya adalah menggunakan uji korelasi dan analisis varian. Semua analisis tersebut dibantu dengan program SPSS V.23.

\section{HASIL DAN PEMBAHASAN}

Gambaran hasil penelitian tentang kemampuan atau kondisi fisik atlet Papua tersaji pada Tabel 3. Untuk atlet atletik laki-laki status IMT yang terbanyak adalah normal yaitu berjumlah 46 atlet $(86,79 \%)$ dan atlet perempuan sebanyak 15 atlet $(78,95 \%)$. Pada aspek kekuatan otot lengan yang terbanyak ada pada kondisi sangat kurang yaitu berjumlah 19 atlet laki-laki $(35,85 \%)$ dan untuk perempuan sebanyak 11 atlet $(57,89 \%)$. Pada variabel kecepatan jumlah terbanyak ada pada kondisi kurang, yaitu sebanyak 21 atlet lakilaki $(39,62 \%)$ sedangkan untuk atlet perempuan yang terbanyak ada pada kondisi sangat kurang yaitu 11 atlet $(57,89 \%)$. Pada aspek daya tahan atau VO2max kondisi terbanyak ada pada kriteria kurang, yaitu sebesar 22 atlet laki-laki $(41,51 \%)$, sedangkan atlet perempuan semuanya memiliki kondisi sangat kurang (19 atlet atau 100\%).

Untuk atlet bola voli laki-laki dan perempuan ditemukan status IMT-nya yang terbanyak adalah normal, yaitu 13 atlet laki-laki $(61,90 \%)$ dan 7 atlet perempuan $(77,78 \%)$. Untuk kekuatan otot lengan ditemukan hasil yang sama antara atlet laki-laki dan perempuan, yaitu jumlah terbanyak ada pada kondisi kurang, 9 atlet laki-laki $(42,86 \%)$ dan 4 atlet perempuan $(44,44 \%)$. Pada variabel kecepatan, baik atlet laki-laki maupun perempuan hasilnya sama, yaitu jumlah terbanyak ada pada kondisi sangat kurang, 14 atlet laki-laki $(66,67 \%)$ dan 8 atlet perempuan $(88,89 \%)$. Pada aspek daya tahan atau VO2max, baik atlet laki-laki maupun perempuan, jumlah terbanyak ada pada kondisi sangat kurang, yaitu 15 atlet laki-laki $(71,43 \%)$ dan 8 atlet perempuan $(88,89 \%)$.

Untuk atlet tarung derajat laki-laki dan perempuan ditemukan status IMT-nya yang terbanyak adalah normal, yaitu 11 atlet laki-laki $(61,11 \%)$ dan 7 atlet perempuan $(58,33 \%)$. Untuk kekuatan otot lengan ditemukan hasil yang sama antara kondisi kurang dan sangat kurang pada atlet laki-laki, yaitu sebanyak 7 atlet $(38,89 \%)$, sedangkan pada atlet perempuan jumlah terbanyak ada pada kondisi kurang, 8 atlet perempuan $(66,67 \%)$. Pada variabel kecepatan, baik atlet laki-laki maupun perempuan hasilnya sama, yaitu jumlah terbanyak ada pada kondisi sangat kurang, 12 atlet laki-laki $(66,67 \%)$ dan 12 atlet 
perempuan (100\%). Pada aspek daya tahan atau VO2max, kriteria terbanyak atlet laki-laki adalah pada kondisi kurang (12 atlet atau 66,67\%), sedangkan atlet perempuan jumlah terbanyak ada pada kondisi sangat kurang, yaitu 7 atlet perempuan $(58,33 \%)$.

Secara keseluruhan, pada variabel IMT, jumlah terbanyak ada pada kriteria normal, 70 atlet laki-laki $(76,09 \%)$ dan 29 atlet perempuan $(72,5 \%)$. Untuk veriabel kekuatan, jumlah terbanyak atlet laki-laki dalam kondisi sangat kurang yaitu sebesar $32(34,78 \%)$ orang sedangkan atlet perempuan ada pada kondisi kurang, yaitu sebanyak $17(42,50 \%)$ orang. Dalam variabel kecepatan, jumlah terbanyak atlet laki-laki dan perempuan berada dalam kondisi yang sama, yaitu sangat kurang, $42(45,65 \%)$ atlet laki-laki dan $31(77,50 \%)$ atlet perempuan. Untuk variabel VO2max jumlah terbanyak atlet laki-laki dan perempuan berada dalam kondisi yang sama, yaitu sangat kurang, $40(43,48 \%)$ atlet laki-laki dan $34(85,00 \%)$ atlet perempuan. Dari gambaran hasil tersebut, tampak bahwa kondisi fisik atlet Papua, baik cabor atletik, bola voli maupun tarung derajat masih belum cukup baik karena rata-rata berada dalam kategori kurang dan sangat kurang. Untuk dapat bersaing di tingkat nasional dibutuhkan peningkatan secara total dalam kualitas fisik yang dimiliki atlet Papua. Tanpa peningkatan kualitas fisik maka sukar rasanya atlet Papua dapat mengapai prestasi maksimal dalam even PON XX di Papua.

Analisis berikutnya diarahkan untuk mengetahui hubungan antara variabel IMT, kecepatan dan kekuatan dengan VO2max. VO2max dijadikan sebagai variabel terikat memiliki dasar yang kuat. Sporis et al. (2008) mengungkapkan bahwa kapasitas daya tahan (VO2max) atlet menjadi aspek krusial yang berdampak pada suatu hasil pertandingan. Kent (Swadesi, 2016) menyebutkan bahwa berdasarkan hasil penelitian pada atlet yang berprestasi tinggi ditemukan VO2maxnya juga tinggi, yaitu berada di atas skor 50 atau berkriteria superior. Bahkan, Debbian Sr. dan Rismayanthi (2016) memberikan pengandaian yang sangat keras yaitu VO2max untuk seorang atlet dapat diibaratkan sebagai nyawa dari performa di lapangan. Ketika skor VO2max atlet tinggi maka kemampuan endurance atau daya tahan jantung dan paru (kardiorespirasi) pasti baik sehingga atlet tidak mudah kelelahan ketika bertanding di lapangan.

Tabel 3. Kondisi Fisik Atlet Papua Antara Laki-Laki dan Perempuan

\begin{tabular}{|c|c|c|c|c|c|c|c|c|c|}
\hline \multirow{3}{*}{ Var } & \multirow{3}{*}{ Krit } & \multicolumn{6}{|c|}{ Cabang Olahraga } & \multicolumn{2}{|c|}{ Total } \\
\hline & & \multicolumn{2}{|c|}{ Atletik } & \multicolumn{2}{|c|}{ Bola Voli } & \multicolumn{2}{|c|}{ Tarung Derajat } & \multirow{2}{*}{$\mathrm{L}$} & \multirow{2}{*}{$\mathrm{P}$} \\
\hline & & $\mathrm{L}$ & $\mathrm{P}$ & $\mathrm{L}$ & $\mathrm{P}$ & $\mathrm{L}$ & $\mathrm{P}$ & & \\
\hline \multirow[t]{5}{*}{ IMT } & Obe & $1(1,89)$ & $1(5.26)$ & $4(19.05)$ & $1(11.11)$ & $1(5.56)$ & $2(16.67)$ & $6(6.52)$ & $4(10.00)$ \\
\hline & Gem & $5(9,43)$ & $0(0)$ & $4(19.05)$ & $1(11.11)$ & $6(33.33)$ & $3(25)$ & $15(16.30)$ & $4(10.00)$ \\
\hline & Nor & $46(86,79)$ & $15(78.95)$ & $13(61.90)$ & $7(77.78)$ & $11(61.11)$ & $7(58.33)$ & $70(76.09)$ & $29(72.50)$ \\
\hline & Kur & $0(0)$ & $2(10.53)$ & $0(0)$ & $0(0)$ & $0(0)$ & $0(0)$ & $0(0)$ & $2(5.00)$ \\
\hline & SKur & $1(1,89)$ & $1(5.26)$ & $0(0)$ & $0(0)$ & $0(0)$ & $0(0)$ & $1(1.09)$ & $1(2.50)$ \\
\hline \multirow[t]{5}{*}{ Kekuatan } & SB & $0(0)$ & $0(0)$ & $1(4.76)$ & $2(22.22)$ & $0(0)$ & $0(0)$ & $1(1.09)$ & $2(5.00)$ \\
\hline & $\mathrm{B}$ & $7(13,21)$ & $0(0)$ & $3(14.29)$ & $0(0)$ & $0(0)$ & $0(0)$ & $10(10.87)$ & $0(0)$ \\
\hline & $\mathrm{C}$ & $18(33,96)$ & $3(15.79)$ & $2(9.52)$ & $3(33.33)$ & $4(22.22)$ & $4(33.33)$ & $24(26.09)$ & $10(25.00)$ \\
\hline & $\mathrm{K}$ & $9(16,98)$ & $5(26.32)$ & $9(42.86)$ & $4(44.44)$ & $7(38.89)$ & $8(66.67)$ & $25(27.17)$ & $17(42.50)$ \\
\hline & SK & $19(35,85)$ & $11(57.89)$ & $6(28.57)$ & $0(0)$ & $7(38.89)$ & $0(0)$ & $32(34.78)$ & $11(27.50)$ \\
\hline \multirow[t]{5}{*}{ Kecepatan } & SB & $0(0)$ & $0(0.00)$ & $0(0)$ & $0(0)$ & $0(0)$ & $0(0)$ & $0(0)$ & $0(0)$ \\
\hline & $\mathrm{B}$ & $5(9,43)$ & $0(0.00)$ & $0(0)$ & $0(0)$ & $2(11.11)$ & $0(0)$ & $7(7.61)$ & $0(0)$ \\
\hline & $\mathrm{C}$ & $11(20,75)$ & $3(15.79)$ & $1(4.76)$ & $0(0)$ & $1(5.56)$ & $0(0)$ & $13(14.13)$ & $3(7.50)$ \\
\hline & $\mathrm{K}$ & $21(39,62)$ & $5(26.32)$ & $6(28.57)$ & $1(11.11)$ & $3(16.67)$ & $0(0)$ & $30(32.61)$ & $6(15.00)$ \\
\hline & SK & $16(30,19)$ & $11(57.89)$ & $14(66.67)$ & $8(88.89)$ & $12(66.67)$ & $12(100)$ & $42(45.65)$ & $31(77.50)$ \\
\hline \multirow[t]{5}{*}{$V O 2 \max$} & SB & $5(9,43)$ & $0(0)$ & $0(0)$ & $0(0)$ & $0(0)$ & $0(0)$ & $5(5.43)$ & $0(0)$ \\
\hline & B & $7(13,21)$ & $0(0)$ & $0(0)$ & $0(0)$ & $0(0)$ & $0(0)$ & 7 (7.61) & $0(0)$ \\
\hline & $\mathrm{C}$ & $0(0)$ & $0(0)$ & $2(9.52)$ & $0(0)$ & $0(0)$ & $0(0)$ & $2(2.17)$ & $0(0)$ \\
\hline & $\mathrm{K}$ & $22(41,51)$ & $0(0)$ & $4(19.05)$ & $1(11.11)$ & $12(66.67)$ & $5(41.67)$ & $38(41.30)$ & $6(15.00)$ \\
\hline & SK & $19(35,85)$ & $19(100)$ & $15(71.43)$ & $8(88.89)$ & $6(33.33)$ & $7(58.33)$ & $40(43.48)$ & $34(85.00)$ \\
\hline
\end{tabular}

\section{Keterangan:}

Obe $=$ obesitas, Gem $=$ gemuk, Nor $=$ normal, Kur $=$ kurus, SKur $=$ sangat kurus

$\mathrm{SB}=$ sangat baik, $\mathrm{B}=$ baik, $\mathrm{C}=$ cukup, $\mathrm{K}=$ kurang, $\mathrm{SK}=$ sangat kurang 
Jurnal Keolahragaan 7 (2), 2019 - 139

Miftah Fariz Prima Putra, Saharuddin Ita

Tabel 4. Uji statistik korelasi antar variabel

\begin{tabular}{llccc}
\hline & & IMT & Kecepatan & Kekuatan \\
\hline VO2max & Pearson Correlation & $-.177^{*}$ & -.163 & $.312^{* *}$ \\
& Sig. (2-tailed) & .042 & .062 & .000 \\
& $N$ & 132 & 132 & 132 \\
\hline
\end{tabular}

*. Correlation is significant at the 0.05 level (2-tailed).

**. Correlation is significant at the 0.01 level (2-tailed)

Hasil analisis korelasi tersaji pada Tabel 4.

Uji statistik tersebut menemukan bahwa terdapat hubungan yang signifikan antara IMT dengan VO2max yang dibuktikan dengan nilai $r$ sebesar 0,177 dan nilai signifikansi $0,042(\alpha<0,05)$. Nilai $r$ yang negatif tersebut mengindikasikan bahwa pola hubungan antara IMT dengan VO2max bersifat negatif, yang bermakna kenaikan nilai IMT akan diikuti penurunan pada nilai VO2max dan begitu juga sebaliknya, penurunan pada nilai IMT akan dikuti kenaikan nilai VO2max. Hasil tersebut sejalan dengan penelitian yang dilakukan oleh Sunadi et al. (2016) menemukan bahwa terdapat hubungan yang signifikan antara IMT dengan VO2max atlet, baik pada pada atlet laki-laki maupun perempuan. Studi yang dilakukan Hidayah dan Muniroh (2017) menemukan bahwa terdapat hubungan negatif antara IMT dengan aspek kemampuan fisik atlet (power).

Uji statistik yang kedua pada variabel kecepatan menemukan tidak terdapat hubungan yang signifikan antara kecepatan dengan VO2max, yang dibuktikan dengan nilai $r$ sebesar $-0,163$ dan nilai signifikansi $0,062(\alpha>0,05)$. Meskipun ditemukan hasil yang tidak sig-nifikan, namun nilai $r$ yang negatif mengindikasi-kan bahwa waktu tempuh atlet yang semakin singkat (cepat) akan diikuti peningkatan pada skor VO2max, dan begitu juga sebaliknya peningkatan skor atau waktu tempuh atlet akan diikuti penurunan skor VO2max.

Hasil penelitian lain yang dilakukan pada atlet atletik di PASI Riau dengan aspek kecepatan yang menjadi variabel utama menemukan bahwa terdapat hubungan yang positif antara kecepatan dengan prestasi lari $800 \mathrm{~m}$ dalam cabor atletik (Saputra et al., 2017). Ditemukannya hubungan yang positif tersebut menunjukkan bahwa peningkatan waktu tempuh variabel kecepatan akan diikuti peningkatan variabel lari $800 \mathrm{~m}$, begitu juga sebaliknya, penurunan waktu tempuh variabel kecepatan akan diikuti penurunan variabel lari $800 \mathrm{~m}$. Riset yang dilakukan oleh Noviatmoko dan Widodo (2016) pada atlet tarung derajat menemukan bahwa variabel kecepatan menjadi salah satu aspek fisik yang dominan dalam menentukan prestasi atlet dalam sebuah pertan-

dingan. Lebih lanjut dijelaskan bahwa $80 \%$ atlet perempuan memiliki kriteria kecepatan yang baik dan sebesar $60 \%$ atlet laki-laki masuk dalam kategori kecepatan baik. Itu artinya, baik untuk cabor atletik maupun cabor beladiri, komponen fisik kecepatan menjadi aspek yang penting dalam kaitanya dengan prestasi atlet.

Peneliti yang mencoba mencari dan menganalisis data tentang kecepatan lari menemukan hasil yang mencenangkan. Pencarian data di internet dengan kata kunci "rekor dunia lari 100 m" menemukan bahwa setelah menggunakan pencatatan waktu elektronik, tahun 1968, rekor dunia dipegang oleh Jim Hines asal AS dengan catatan waktu 9,95 detik. Dua puluh tahun berikutnya, yaitu 1988 rekor dunia menjadi milik Carl Lewis asal AS dengan waktu 9,92 detik. Dua puluh tahun selanjutnya, tepatnya tahun 2008, rekor dunia dipegang oleh pelari asal Jamaika, Usain Bolt, dengan catatan waktu 9,69 detik. Rekor tersebut Ia pecahkan sendiri pada tahun 2009 dengan catatan waktu 9,58 detik dan rekor tersebut sampai saat ini belum terpecahkan.

Mencermati data tersebut, tampak bahwa dalam kurun waktu 41 tahun (1968-2009) terjadi perbaikan waktu hanya 0,37 detik, yaitu dari 9,95 menjadi 9,58 detik. Melihat data tersebut, tidak mengherankan bila banyak pihak mengatakan dibutuhkan waktu yang tidak sebentar untuk melakukan perbaikan catatan waktu dalam cabang olahraga yang unsur kecepatanya dominan. Artinya, kembali lagi sesuai dengan pernyataan bahwa kecepatan menjadi faktor yang sangat penting dan menarik dikaji dalam olahraga prestasi (PON). Di samping itu, kecepatan dapat menjadi indikator tingkat kebugaran komponen fisik yang lain. Misalnya, ketika atlet mampu berlari dengan cepat pada jarak 200m, maka selain memiliki kecepatan, atlet tersebut juga memiliki kekuatan, daya tahan serta kondisi yang baik pada sistem kardiovaskulernya.

Hasil uji statistik yang ketiga pada variabel kekuatan menemukan terdapat hubungan yang signifikan antara kekuatan dengan VO2max yang dibuktikan dengan nilai $r$ sebesar 0,312 dan nilai signifikansi $0,000(\alpha<0,05)$. Hal tersebut mengindikasikan bahwa pola hubungan antara kekuatan dengan VO2max bersifat positif. Itu artinya, 
kenaikan nilai kekuatan akan diikuti kenaikan pula pada nilai VO2max, begitu juga sebaliknya, penurunan nilai kekuatan akan diikuti penurunan nilai VO2max. Signifikansi korelasi antara kekuatan dengan $V O 2 \max$ terjadi baik pada tingkat $5 \%(0,05)$ maupun $1 \%(0,01)$.

Variabel kekuatan perlu diperhatikan dalam cabor yang mengandalkan unsur kekuatan. Sebagai contoh, haisl penelitian yang dilakukan oleh Ramsi \& Widodo (2015) yang mengaitkan antara variabel kekuatan dengan prestasi pukulan smash dalam permainan bola voli menemukan bahwa terdapat hubungan yang signifikan antara kekuatan dengan prestasi pukulan smash dengan nilai $r$ sebesar 0,87 . Nilai $r$ tersebut menunjukan betapa kuatnya hubungan antara kekuatan dengan prestasi atau keterampilan dalam olahraga. Pada cabor beladiri, misalnya cabor wushu, hasil penelitian menunjukkan bahwa terdapat hubungan yang signifikan antara variabel kekuatan dengan prestasi wushu (Arya \& Wijono, 2017). Pada cabor atletik, studi yang dilakukan oleh Yundarwati dan Primayanti (2016) pada nomor lempar cakram menemukan bahwa terdapat hubungan yang signifikan antara kekuatan otot lengan dengan prestasi lemparan cakram.

Dari tiga variabel bebas yang diuji, terdapat dua variabel yang memiliki hubungan yang signifikan dengan VO2max atlet, yaitu IMT dan kekuatan. Meskipun variabel kecepatan memiliki nilai $\mathrm{r}$ 0,06 atau bermakna tidak terdapat hubungan yang signifikan secara statistik, namun bukan berarti variabel tersebut tidak berkaitan sama sekali dengan VO2max atlet. Nilai r 0,062 merupakan nilai yang hampir mendekati adanya hubungan yang signifikan. Selain itu, baik komponen fisik kecepatan maupun VO2max merupakan aspek fisik yang sangat penting dalam kaitannya dengan capaian prestasi atlet di lapangan.

Analisis selanjutnya dirahkan untuk mengetahui perbedaan kemampuan fisik atlet Papua antara cabor atletik, bola voli dan tarung derajat. Hasil uji statitik tersaji pada Tabel 5. Dari hasil tersebut tampak bahwa pada variabel IMT didapat nilai $F$ sebesar 10,996 dengan nilai signifikansi $0,0001(\alpha<0,05)$ yang bermakna terdapat perbedaan yang signifikan pada variabel IMT antara cabor atletik, bola voli dan tarung derajat. Dilihat dari nilai rata-rata IMT pada Gambar 1 tampak bahwa atlet cabor bola voli memiliki skor yang lebih tinggi $(24,26)$ dibanding dengan cabor tarung derajat (23.80) dan atletik (21.75).

Tampak bahwa variabel IMT atlet bola voli skornya yang lebih tinggi dibanding cabor lainnya. Dalam konteks ini, tingginya IMT yang dimiliki atlet bola boli bukan berarti atlet bola voli masuk dalam kategori obesitas. Data menunjukkan bahwa rata-rata atlet bola voli IMT-nya masuk dalam kategori normal. Namun, tidak dapat dipungkiri bahwa tinggi badan yang dimiliki atlet akan sangat mambantu dalam permainan di lapangan. Bahkan, kegagalan tim bola voli Indonesia dalam babak kualifikasi olimpiade di Portugal disinyalir karena faktor tinggi badan. Maspaitella, mantan toser pemain nasional, mengatakan bahwa keunggulan teknik pemain bola voli bila tidak didukung dengan tinggi badan maka akan sia-sia (Donny, 2008).

Hasil yang kedua pada variabel kecepatan menemukan nilai $\mathrm{F}$ sebesar 5,140 dengan nilai signifikansi $0,007(\alpha<0,05)$ yang bermakna terdapat perbedaan yang signifikan pada variabel kecepatan antara cabor atletik, bola voli dan tarung derajat. Dilihat dari nilai rata-rata kecepatan pada Gambar 1 tampak bahwa atlet cabor atletik memiliki skor rata-rata kecepatan yang lebih baik $(4,64)$ dibanding dengan cabor tarung derajat $(6,54)$ dan bola voli $(6,86)$.

Hasil studi yang dilakukan oleh M. R. Setiawan dan Mintarto (2017) menemukan bahwa atlet atletik memiliki kemampuan lari dengan kategori yang baik sebesar 70\%. Dengan demikian tidak mengherankan bila ditemukan nilai ratarata cabor atletik yang lebih kecil dibanding dengan cabor lainnya. Hal ini mengindikasikan bahwa cabor atletik lebih dominan unsur kecepatannya, terutama untuk nomor lari. Hal yang berbeda ditemui pada cabor bola voli dan tarung derajat, yaitu unsur kecepatan berlari tidak menjadi aspek yang dominan. Studi yang dilakukan oleh Aldera dan Ismalasari (2018) menemukan bahwa tidak ada atlet beladiri (anggar) yang memiliki kategori kecepatan baik atau sangat baik.

Dengan demikian didapatnya hasil penelitian yang menemukan terdapat perbedaan kecepatan antara cabor atletik, bola voli dan tarung derajat dapat disebabkan karena cabor atletik memiliki nilai rata-rata yang jauh lebih baik dibanding dua cabor lainnya. Kedua, aspek kecepatan untuk cabor bola voli dan tarung derajat tidak terlalu dominan sehingga sangat bisa jadi pelatih tidak membuat program secara khusus untuk meningkatkan kecepatan atlet. Komponen fisik lainnya, seperti kekuatan otot tungkai, lengan, perut serta koordinasi dapat menjadi alternatif pilihan dalam cabor bola voli dan tarung derajat untuk menjadi sasaran utama dinaikan kualitasnya. 
Jurnal Keolahragaan 7 (2), 2019 - 141

Miftah Fariz Prima Putra, Saharuddin Ita

Tabel 5. Hasil Uji Beda Antar Cabor

\begin{tabular}{llccccc}
\hline Variabel & Cabang Olahraga & $\mathrm{N}$ & Mean & Std. Dev. & F & Sig. \\
\hline IMT & Atletik & 72 & 21.75 & 2.52 & & \\
& Bola voli & 30 & 24.26 & 2.89 & 10.996 & .000 \\
& Tarung derajat & 30 & 23.80 & 3.33 & & \\
& Total & 132 & 22.78 & 3.01 & & \\
\hline Kecepatan & Atletik & 30 & 4.64 & 0.76 & & .007 \\
& Bola voli & 30 & 6.86 & 4.34 & 5.140 & \\
& Tarung derajat & 132 & 6.54 & 6.40 & & \\
& Total & 72 & 5.58 & 3.82 & & \\
\hline Kekuatan & Atletik & 30 & 28.90 & 7.52 & & \\
& Bola voli & 30 & 28.90 & 11.43 & 2.148 & \\
& Tarung derajat & 132 & 24.73 & 7.24 & & \\
& Total & 72 & 27.49 & 8.58 & & \\
& Atletik & 30 & 39.68 & 7.66 & & \\
& Bola voli & 30 & 38.18 & 7.02 & 12.521 & .000 \\
& Tarung derajat & 132 & 31.73 & 6.91 & & \\
& Total & 30 & 37.53 & 7.98 & &
\end{tabular}

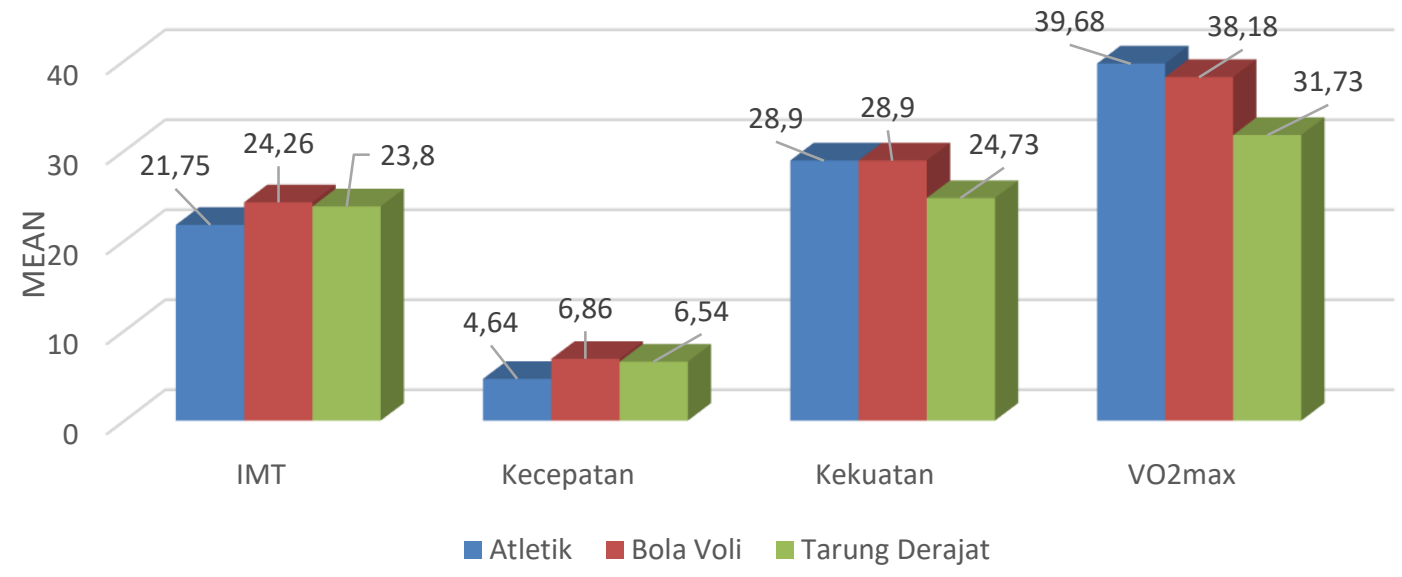

Gambar 1. Perbandingan nilai rata-rata

Hasil yang ketiga pada variabel kekuatan menemukan nilai $\mathrm{F}$ sebesar 2,148 dengan nilai signifikansi $1,121(\alpha>0,05)$ yang bermakna tidak terdapat perbedaan yang signifikan pada variabel kekuatan antara cabor atletik, bola voli dan tarung derajat. Dilihat dari nilai rata-rata kekuatan pada Gambar 1 tampak bahwa atlet cabor atletik dan bola voli memiliki skor yang sama besar $(28,90)$ dibanding dengan cabor tarung derajat $(27,49)$.

Hasil penelitian yang dilakukan Irwasnyah et al. (2016) pada atlet atletik menemukan terdapat hubungan yang signifikan antara kekuatan otot lengan dengan kemampuan tolak peluru. Selain itu, variabel kekuatan juga berkontribusi sebsar 30\% terhadap kemampuan tolakan atlet. Hasil studi yang lain ternyata menunjukkan tidak hanya pada nomor yang mengandalkan aspek lengan seperti tolak peluru, namun dalam nomor lari juga berkontribusi untuk atlet. Riset yang dilakukan oleh Nurdin dan Kemala (2012) menunjukkan bahwa terdapat hubungan yang negatif antara kekuatan otot lengan dengan waktu tempuh berlari. Itu artinya, semakin kuat otot lengan yang dimiliki atlet atletik maka akan semakin pendek waktu tempuh berlari atau dengan kata lain atlet akan semakin kencang berlarinya.

Untuk cabor bola voli, kekuatan otot lengan menjadi salah satu aspek fisik yang sangat penting, terutama dalam gerakan servis dan smash. Hasil penelitian yang dilakukan oleh Gazali (2016) menemukan bahwa kekuatan otot lengan yang dimiliki oleh atlet bola voli memiliki kontribusi positif terhadap kemampuan servis atlet, terutama servis atas. Studi yang dilakukan oleh Anam et al. (2015) menujukkan bahwa kekuatan otot lengan memberikan sumbangan yang signifikan terhadap kemampuan smash atlet. Dengan demikian kekuatan otot lengan menjadi aspek yang penting untuk atlet bola voli. Pada cabor tarung derajat hasil studi ini senada dengan 
penelitian yang dilakukan oleh I. Setiawan dan Allsabah (2018) yang menemukan bahwa atlet tarung derajat Kediri memiliki nilai rata-rata (55\%) kekuatan otot dalam kategori kurang.

Hasil yang keempat pada variabel VO2max menemukan nilai $\mathrm{F}$ sebesar 12,421 dengan nilai signifikansi $0,0001(\alpha<0,05)$ yang bermakna terdapat perbedaan yang signifikan pada variabel VO2max antara cabor atletik, bola voli dan tarung derajat. Dilihat dari nilai rata-rata VO2max pada Gambar 1 tampak bahwa atlet cabor atletik memiliki skor yang lebih besar $(39,68)$ dibanding dengan cabor bola voli $(38,18)$ dan tarung derajat (31.73).

VO2max atlet untuk setiap cabang olahraga besaranya berbeda-beda. Hal ini terjadi karena terdapat perbedaan karakteristik gerakan dalam cabang olahraga. Sebagai contoh, hasil studi yang dilakukan Nugraheni et al. (2017) terhadap atlet di Semarang menemukan untuk atlet cabor bola voli VO2max sebesar 40,84 $\mathrm{ml} / \mathrm{kg} / \mathrm{mnt}$, untuk cabor bola basket sebesar 42,15 $\mathrm{ml} / \mathrm{kg} / \mathrm{mnt}$, taekwondo sebesar $35,39 \mathrm{ml} / \mathrm{kg} / \mathrm{mnt}$, dan karate sebesar $34,25 \mathrm{ml} / \mathrm{kg} / \mathrm{mnt}$. Studi yang dilakukan oleh Zuhri dan Sulistyarto (2016) pada atlet putri bola voli menemukan bahwa rata-rata $(66,6 \%)$ memiliki kriteria VO2max sedang. Kajian yang dilakukan oleh Junaidi (2014) terhadap atlet softball Indonesia yang masuk dalam program Indonesia Emas menemukan bahwa tidak ada atlet yang mendapat nilai endurance cukup apalagi baik VO2max-nya. Hal yang senada juga diungkap oleh Kusnanik (2014) bahwa kapasitas VO2max atlet taekwondo dalam kategori kurang. Penelitian yang dilakukan oleh Aldera dan Ismalasari (2018) pada atlet anggar menemukan bahwa VO2max atlet berada pada kategori kurang (40) dan sangat kurang (60\%).

Bagaimana dengan VO2max atlet internasional? Carling et al. (2009) menyebutkan untuk atlet sepakbola di liga Spanyol rata-rata VO2max yang dimiliki adalah $66,4 \mathrm{ml} / \mathrm{kg} / \mathrm{mnt}$, sedangkan pemain nasional Australia rata-ratanya adalah $57,6 \mathrm{ml} / \mathrm{kg} / \mathrm{mnt}$. Dari data tersebut tampak bahwa terjadi perbedaan selisih yang cukup besar antara atlet nasional dengan atlet internasional. Berbagai hasil penelitian terhadap atlet nasional di atas menunjukkan nilai VO2max yang jauh dari kata memuaskan untuk ukuran atlet berlabel nasional. Itu artinya, meskipun menjadi variabel yang sangat penting, namun malangnya kondisi VO2max (endurance) atlet sangat menyedihkan. Padahal, Sporis et al. (2008) kalau kapasitas daya tahan (VO2max) atlet merupakan aspek krusial yang berdampak lang- sung pada suatu hasil pertandingan. Hasil penelitian yang dilakukan oleh Tanzila dan Febriani (2019) menemukan bahwa terdapat korelasi positif antara VO2max dengan prestasi atlet bola voli, beladiri, dan renang. Ketika atlet memiliki skor VO2max yang tinggi maka kemampuan endurance atau daya tahan jantung dan paru (kardiorespirasi) atlet yang bersangkutan akan dapat bersaing dengan lawan.

Berkaitan dengan kejuaraan multi even seperti PON, Suharjana (2012) menyebutkan kebugaran aerobik (kondisi fisik atlet) yang berkriteria baik dan baik sekali menjadi syarat yang harus dimiliki oleh setiap atlet. Tanpa kondisi fisik yang baik, sukar prestasi yang optimal dapat digapai. Mencermati data kondisi fisik yang dimiliki oleh atlet Papua maka ada pekerja rumah yang sangat besar bagi pelatih dan pengurus cabor untuk meningkatkan kondisi fisik atlet di Papua sebelum even olahraga terbesar digelar tahun 2020. Atlet yang pantas untuk mengikuti pertandingan atau perlombaan adalah yang memiliki kondisi fisik prima dan kriteria kondisi fisiknya setara atau di atas standar nasional. Tanpa hal itu, sukar atlet Papua dapat bersaing dan berprestasi pada even olahraga terbesar tanah air (PON).

\section{SIMPULAN}

Hasil penelitian ini menemukan bahwa kondisi IMT atlet Papua rata-rata berkriteria normal, aspek fisik kekuatan rata-rata berkriteria sangat kurang untuk laki-laki dan kurang untuk atlet perempuan, aspek fisik kecepatan rata-rata dalam kondisi sangat kurang, dan aspek fisik VO2max rata-rata dalam kondisi sangat kurang. Temuan kedua menunjukkan terdapat hubungan antara IMT dan kekuatan dengan VO2max, sedangkan dengan kekuatan tidak ada hubungan yang signifikan. Hasil penelitian ketiga menujukkan bahwa terdapat perbedaan yang signifikan pada kondisi fisik IMT, kecepatan dan VO2max atlet antara cabor atletik, bola voli dan tarung derajat. Untuk kondisi fisik kekuatan tidak terdapat perbedaan yang signifikan. Rekomendasi yang dapat diberikan bertalian dengan temuan tersebut adalah kondisi fisik yang masih berkriteria sangat kurang dan kurang perlu dibenahi agar kualitas fisik atlet Papua meningkat. Untuk studi berikutnya hendaknya diarahkan pada aspek fisik yang lebih komprehensif seperti kelincahan, keseimbangan, kekuatan otot perut dan power serta melibatkan cabor dan atlet yang lebih luas. 


\section{DAFTAR PUSTAKA}

Aggraeni, Y. (2013). Kontribusi IQ (intelligent quotient) dan EQ (emotional quotient) terhadap prestasi atlet pelatda pencak silat pada PON ke-XVIII tahun 2012. Jurnal Phederal Penjas, 1(1), 1-13. https://www.jurnal.fkip.uns.ac.id/index.ph p/penjaskesrek/article/view/958

Aldera, N., \& Ismalasari, R. (2018). Analisis kecepatan, kelincahan, kekuatan dan vo2max terhadap atlet cabang olahraga anggar putra Kabupaten Situbondo. Jurnal Prestasi Olahraga, 3(1), 1-3. https://jurnalmahasiswa.unesa.ac.id/index. php/jurnal-prestasi-

olahraga/article/view/22961

Anam, K., Nasuka, N., \& Aji, T. (2015). Klub bola voli putra Ivokas Kabupaten Semarang. Journal of Sport Sciences, 4(1), 40-49.

https://journal.unnes.ac.id/sju/index.php/u jss/article/view/8637

Ary, D., Jacobs, L. C., Sorensen, C., \& Razavieh, A. (2010). Introduction to research in education. Wadsworth, Cengage Learning.

Arya, P. A., \& Wijono, W. (2017). Hubungan kondisi fisik terhadap prestasi atlet wushu sanda di Sasana Kim Tiauw Surabaya. Jurnal Prestasi Olahraga, 1(1), 1-11. https://jurnalmahasiswa.unesa.ac.id/index. php/jurnal-prestasi-

olahraga/article/view/19489

Bompa, T. O., \& Haff, G. (2009). Periodization: Theory and methodology of training. Human Kinetics.

Carling, C., Reilly, T., \& Williams, A. M. (2009). Performance assessment for field sports. Routledge.

Debbian Sr., A., \& Rismayanthi, C. (2016). Profil tingkat volume oksigen maskimal (VO2 max) dan kadar hemoglobin (HB) pada atlet Yongmoodo Akademi Militer Magelang. Jorpres (Jurnal Olahraga Prestasi), 12(2), 19-30. https://doi.org/10.21831/jorpres.v12i2.118 74

Dimyati, D. (2004). Kepercayaan diri atlet PON DIY menghadapi PON XVI di Palembang. Jurnal Penelitian Humaniora, 9(2), 62-72. https://journal.uny.ac.id/index.php/human iora/article/view/6093

Donny. (2008). Tinggi badan mutlak bagi pemain bola voli. Vollimania.Org. http://volimania.org/index.php?option=co m_content\&task=view\&id=1647\&Itemid $=75$

Gazali, N. (2016). Kontribusi kekuatan otot lengan tehadap kemampuan servis atas atlet bolavoli. Journal of Physical Education, Health and Sport, 3(1), 1-6. https://doi.org/10.15294/jpehs.v3i1.6496

Hambali, H., Syamsulrizal, S., \& Ifwandi, I. (2016). Komponen mendasar kondisi fisik atlet tarung derajat Kota Banda Aceh. Jurnal Ilmiah Mahasiswa Penjaskesrek, 1(2), 121-132. http://www.jim.unsyiah.ac.id/penjaskesre k/article/view/1434

Hidayah, L. M., \& Muniroh, L. (2017). Hubungan tingkat kecukupan energi, protein dan indeks massa tubuh (IMT) dengan power atlet beladiri. Media Gizi Indonesia, 12(1), 34-39. https://doi.org/10.20473/mgi.v12i1.34-39

Irwasnyah, I., Saripin, S., \& Wijayanti, N. P. N. (2016). Kontribusi kekuatan otot lengan dengan kemampuan tolak peluru siswa SMA Negeri 1 Kubu. Jurnal Online Mahasiswa (JOM) Bidang Keguruan Dan Ilmu Pendidikan, 3(2), 1-10.

Junaidi, J. (2013). Cedera olahraga pada atlet pelatda PON XVIII DKI Jakarta. Fisioterapi: Jurnal Ilmiah Fisioterapi, 13(1), 12-16. https://ejurnal.esaunggul.ac.id/index.php/ Fisio/article/view/642

Junaidi, J. (2014). Profiles of biomotor ability in both male and female softball athletes of Indonesian Gold Program 2014. International Seminar of Sport and Exercise Science 2014, 168-178.

Kusnanik, N. W. (2014). Antropometric and physical fitness characteristics of male junior taekwondo athletes. International Seminar of Sport and Exercise Science 2014, 430-437.

Noviatmoko, F., \& Widodo, A. (2016). Analisis komponen kondisi fisik dominan dalam cabang olahraga tarung derajat. Jurnal Kesehatan Olahraga, 6(2), 441-449. https://jurnalmahasiswa.unesa.ac.id/index. php/jurnal-kesehatanolahraga/article/view/17502

Nugraheni, H. D., Marijo, M., \& Indraswari, D. A. (2017). Perbedaan nilai VO2max atlet 
cabang olahraga permainan dan bela diri. Jurnal Kedokteran Diponegoro, 6(2), 622-631.

https://ejournal3.undip.ac.id/index.php/me dico/article/view/18580

Nurdin, F., \& Kemala, A. (2012). Kekuatan otot lengan atlet atletik PPLP DKI Jakarta. Gladi Jurnal Ilmu Keolahragaan, 6(1), 492-501.

http://journal.ppsunj.org/gjik/article/view/ 92

Purba, P. H. (2016). Profil Kondisi fisik dan motivasi berprestasi atlet karate Sumut persiapan Pra-PON tahun 2015. Generasi Kampus, 9(1), 78-91. https://jurnal.unimed.ac.id/2012/index.ph $\mathrm{p} / \mathrm{gk} /$ article/view/7418

Rahmat, Z. (2017). Analisis kebijakan KONI Aceh dalam penyelenggaraan training center (TC) atlet PON Aceh tahun 2016. Jurnal Penjaskesrek, 4(2), 107-125.

Ramsi, M., \& Widodo, A. (2015). Hubungan antara kekuatan otot lengan dengan prestasi smash bolavoli. Jurnal Kesehatan Olahraga, 3(1), 166-169. https://jurnalmahasiswa.unesa.ac.id/index. php/jurnal-kesehatanolahraga/article/view/11190

Razak, A. (2011). Studi analisis physical fitnes training terhadap hasil prestasi atlet karate PON XVII di Kaltim tahun 2008. COMPETITOR: Jurnal Pendidikan Kepelatihan Olahraga, 3(1), 214-224. https://ojs.unm.ac.id/competitor/article/vi ew/652

Saputra, M., Ramadi, R., \& Juita, A. (2017). Hubungan daya tahan dan kecepatan terhadap hasil lari 800 meter putra pada atlet atletik PASI Riau. Jurnal Online Mahasiswa (JOM) Bidang Keguruan Dan Ilmu Pendidikan, 4(1), 1-12. https://jom.unri.ac.id/index.php/JOMFKI $\mathrm{P} /$ article/view/14146

Septian, D. A. (2013). Studi tentang manajamen atlet panahan pada NASA Archery club Ponorogo dari tahun 2007 sampai 2011. Jurnal Phederal Penjas, 1(1), 23-33.

Setiawan, I., \& Allsabah, M. A. H. (2018). Profil tingkat kondisi fisik atlet tarung derajat Kota Kediri dalam mempersiapkan kejuaraan Porprov tahun 2018. Briliant: Jurnal Riset Dan Konseptual, 3(4), 488497. https://doi.org/10.28926/briliant.v3i4.251

Setiawan, M. R., \& Mintarto, E. (2017). Profil kondisi fisik atlet lari sprint Ronggolawe atletik club Kabupaten Tuban. Jurnal Prestasi Olahraga, 2(1), 1-6. https://jurnalmahasiswa.unesa.ac.id/index. php/jurnal-prestasi-

olahraga/article/view/22830

Sporis, G., Ruzic, L., \& Leko, G. (2008). The anaerobic endurance of elite soccer players improved after a high-intensity training intervention in the 8-week conditioning program. Journal of Strength and Conditioning Research, 22(2), 559-466. https://doi.org/10.1519/JSC.0b013e31816 60401

Suharjana, S. (2012). Pentingnya kebugaran aerobik bagi setiap atlet yang bertanding pada kejuaraan multi event. Medikora, IX(1), 1-10. https://journal.uny.ac.id/index.php/medik ora/article/view/4643

Sujatno, M. (2001). Pengaruh penggunaan doping terhadap penampilan atlet pada pekan olah raga nasional XIV/1996 dan South East Asian Games XIX/1997 di Jakarta. Jurnal Kedokteran Maranatha, 1(1), 32-38.

Sunadi, D., Soemarji, A. A., Apriantono, T., \& Wirasoetisna, K. R. (2016). Peningkatan VO2max dan analisis korelasi variabel yang mempengaruhinya. JSKK (Jurnal Sains Keolahragaan Dan Kesehatan), 1(1), 17-22. https://doi.org/10.5614\%2Fjskk.2016.1.1. 6

Swadesi, I. K. I. (2016). Standardisasi kondisi fisik atlet Porprov Bali. Seminar Nasional Riset Inovatif, 152-159. https://eproceeding.undiksha.ac.id/index.p $\mathrm{hp} /$ senari/article/view/839

Tanzila, R. A., \& Febriani, R. (2019). Korelasi kapasitas vital paru dengan prestasi atlet di Sekolah Olahraga Nasional Sriwijaya Palembang. Syifa' MEDIKA: Jurnal Kedokteran Dan Kesehatan, 9(2), 79-85. https://doi.org/10.32502/sm.v9i2.1661

Yundarwati, S., \& Primayanti, I. (2016). Hubungan antara kekuatan otot lengan dan panjang lengan terhadap prestasi lempar cakram pada siswa kelas X SMAN 3 Praya tahun pelajaran 2015/2016. Jurnal Ilmiah Mandala Educatio, 2(1), 28-32. 
Jurnal Keolahragaan 7 (2), 2019 - 145

Miftah Fariz Prima Putra, Saharuddin Ita

https://doi.org/10.36312/jime.v2i1.96

Zuhri, M. S., \& Sulistyarto, S. (2016). Analisis Kapasitas kerja maksimal (Vo2max) atlet putri bola voli Sidoarjo Jaya pada usia 16-
18 tahun. Jurnal Kesehatan Olahraga, 4(3), 1-5. https://jurnalmahasiswa.unesa.ac.id/index. php/jurnal-kesehatanolahraga/article/view/17390 